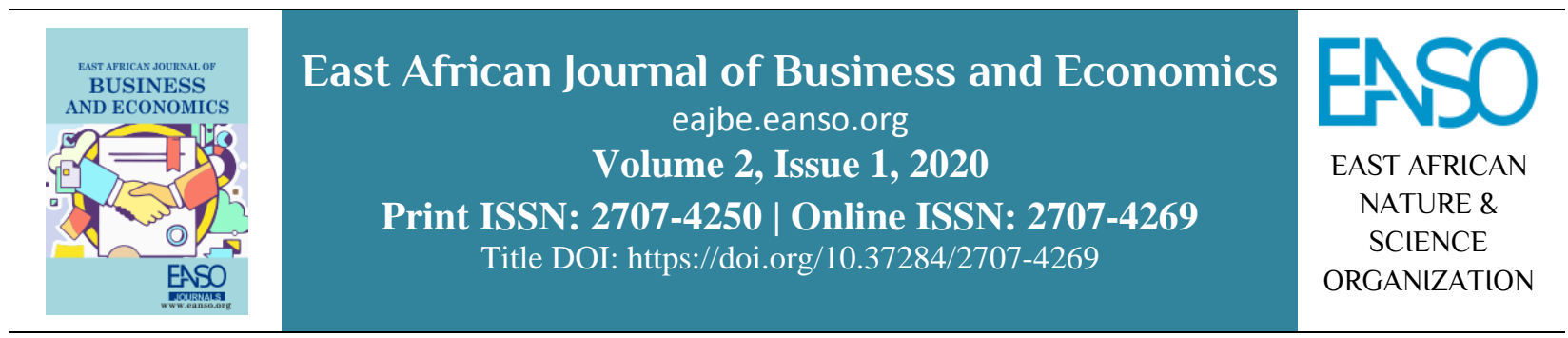

Original Article

\title{
Statistical Analysis of Inventory Management Systems on Organizational Performance
}

\author{
Yoweri Rutagira ${ }^{1}$ \& Richard Opaka Awichi, $P h D^{2 *}$ \\ ${ }^{1}$ Department of Monitoring and Evaluation Plan International Uganda, P. O. Box 12075 Kampala, Uganda and Uganda Martyrs \\ University P. O. Box 5498 Kampala, Uganda. \\ ${ }^{2}$ Department of Mathematics, Faculty of Science and Education, Busitema University, P. O. Box 236 Tororo, Uganda. \\ *Author for correspondence email: ichbinrao@gmail.com or rawichi@sci.busitema.ac.ug. \\ *ORCID: https://orcid.org/0000-0003-1753-7325
}

Article DOI: https://doi.org/10.37284/eajbe.2.1.163

\section{Date Published: ABSTRACT}

11 June 2020 The main purpose of the study was to investigate the effect of physical distribution management on organizational performance by Rutungu

Keywords: Distributors Ltd, Kampala (U). The study assessed the relationship between

Order Processing,

Storage,

Inventory Control,

Transportation,

Organizational

Performance. order processing and organizational performance in Rutungu Distributors Ltd in an attempt to establish the relationship between storage and organizational performance in the organization. It also sought to find out the relationship between other aspects of inventory management on organizational performance within the company. The research used a case study design approach which was correlational considering both quantitative and qualitative approaches in the data collection, presentation, and analysis. The population of the study was several categories of employees of the company. Findings from the study depicted that there is a positive significant relationship between order processing and organizational performance implying that when a customer submits an order, it is verified to ensure the necessary information is included and processed promptly. Storage and organizational performance; this means that the company can reduce damage through good materials handling. There was a positive significant relationship between inventory control and organizational performance as a result of heavy investment in inventory control practices and procedures. There was also a positive significant relationship between transportation and organizational performance showing that the company has an effective automated transportation system, observes wellcoordinated fleet management practices, and also has a good vehicle maintenance policy. The study thus recommends the company to continue 
reducing the time it takes to get an order to a customer's premises and to replenish its stores as it is what every company desires, but while faster fulfilment and small order sizes make customers, and store managers happy, faster fulfilment comes at a cost.

\section{APA CITATION}

Rutagira, Y., \& Awichi, R. (2020). Statistical Analysis of Inventory Management Systems on Organizational Performance. East African Journal of Business and Economics, 2(1), 20-28. https://doi.org/10.37284/eajbe.2.1.163

\section{CHICAGO CITATION}

Rutagira, Yoweri, and Richard Awichi. 2020. "Statistical Analysis of Inventory Management Systems on Organizational Performance”. East African Journal of Business and Economics 2 (1), 20-28. https://doi.org/10.37284/eajbe.2.1.163.

\section{HARVARD CITATION}

Rutagira, Y. and Awichi, R. (2020) "Statistical Analysis of Inventory Management Systems on Organizational Performance", East African Journal of Business and Economics, 2(1), pp. 20-28. doi: 10.37284/eajbe.2.1.163.

\section{IEEE CITATION}

Y. Rutagira and R. Awichi, "Statistical Analysis of Inventory Management Systems on Organizational Performance", EAJBE, vol. 2, no. 1, pp. 20-28, Jun. 2020.

\section{MLA CITATION}

Rutagira, Yoweri, and Richard Awichi. "Statistical Analysis of Inventory Management Systems on Organizational Performance". East African Journal of Business and Economics, Vol. 2, no. 1, Jun. 2020, pp. 20-28, doi:10.37284/eajbe.2.1.163

\section{INTRODUCTION}

The rationale of this study was to assess the relationship between physical distribution and organizational performance in Rutungu Distributors Ltd. Distribution involves the channels of how products are delivered to customers. Organizations can either use intermediaries to market and deliver products or independently manage the steps in the distribution process. Some of the distribution channels used by organizations include use of a direct sales force, wholesale relationships, distributor relationships or retailers. Proper management of these distribution channels can contribute to the performance of an organization.

Until the late 1950s, most firms were more concerned with the promotion and merchandising of their products than about their distribution (McKinnon, 1989). Though some of the early authorities in marketing regarded physical distribution as a key element in marketing strategy, (La Londe and Dawson, 1969), most firms did not grasp its importance. This is evidenced in their "preoccupation with planning, production, purchasing and sales," relegating the actual movement of finished goods to a secondary role (Pirttilä \& Hautaniemi, 1995).

Physical distribution is the set of activities connected with efficient movement of finished goods from the end of the production operation to the consumer. It can be done within a number of warehousing and retailing distribution channels, together with all its important areas as customer services, inventory control, protective packaging, order processing, transportation, site location and warehousing.

Distributive functions were usually regarded as low-grade nuisances, accorded little managerial status and assigned less able staff. Warehousing was considered a "necessary evil and freight transport a dismal calculus on rates and routes and "neither activity was felt to make a significant contribution to the profitability nor to be worthy on much capital investment (McKinnon, 1989). During this period, a certain amount of inefficiency in distribution could be tolerated.

The procedure of getting the right quantity of the right product to the right place at the right time and the least cost is no simple job because companies like the brewery industries with their great diversity 
of customers spread over vast geographical areas must integrate the components of the system to avoid dissonance (Feldman, 2010).

Physical distribution in an organization is generally intended to achieve an increased and efficient movement of finished products from the end production line to the consumer. A generally well designed and executed distribution process is ideally the starting point for proper integration of the activities that eventually lead to the achievement of the organizational goals. When consumers are not properly connected through an organizational distribution channel, the problem of where, when and at what price the company's products will be available will be difficult to ascertain. Similarly, at the Rutungu Distributors Ltd, physical distribution plays a great role such as storage and distribution of organization supplies. Even though physical distribution plays a big role at Rutungu Distributors Ltd, but still, it is faced with problems. Rutungu Distributors Ltd Financial Report (2017) found that poor distribution infrastructure in terms of transportation facilities, that is a small number of tracks used by transporters. According to Kapoor \& Kansal (2005), problems in transportation services can lead to a company retaining the inventory for several days more than had planned for. This increases inventory carrying cost and decreases the number of times inventory is converted into cash.

\section{LITERATURE REVIEW}

\section{Order Processing and Organizational Performance}

Kapoor and Kansal (2015) defined order processing as a group of activities which need to be performed in order to serve the ultimate market. Antún (2016) noted that the accuracy, reliability, and speed with which orders are received, handled, and filled are crucial customer's service factors. Order processing activities include order receipt, credit approval, invoice preparation, and collection of accounts receivable. These activities cut across departmental lines, coordination between sales and office personnel is necessary. The longer salespeople wait to submit orders to office personnel, the less efficient the system becomes. Once an order is received in the office, it must be invoiced quickly; order-picking instructions must be sent to the warehouse, and transportation instructions must be sent to the traffic department.

Variability in the timing of these activities causes unreliable delivery and customer complaints. It is thus very important to analyse the variability to reduce it (Britz et al., 2000). Logistics managers also should be able to give customers up-to-date information about the status of their orders. Fast and accurate filling of orders reduces the time customers must wait to receive shipments. The more reliable a seller is in meeting delivery dates, the better customers loyalty due to reliability.

The idea of impacts of order processing has been expounded upon by various authors; for example, Ebert and Griffin (2012) and Lai et al. (2011) noted that errors such as filling a buyer's order incorrectly are both costly to retailers and irritating to customers. The information transmitted on orders is essential. Errors, delays and incomplete information can cause distribution problems. Ineffective order processing can result in orders taking too long to fill, being shipped to the wrong customers, being inaccurately filled, and not being billed properly.

\section{Storage and Organizational Performance}

In this paper, storage refers to the temporary storage of finished goods until they are required and sold. The logic here is that production and consumption cycles hardly match. The storage function helps to smooth discrepancies between production and the quantities demanded by the market. The company must thus decide on the number and location of the warehouses - depots, sub-depots, wholesalers and retailers (Kotler, 2001) and whether they should be company-owned or rented.

Storage and its accompanying function of finance give depth to the market. Storage is a means of which commodities are protected from deterioration and surplus supplies are carried over for future consumption in periods of scarcity. Storage gives dimensions to the market for a commodity, that is, time and place utility is invested in goods through the storage process, for it involves decisions on what to store where and when. The economic factors associated with storage include 
location, space utilization and product preservation (McKinnon, 1989).

\section{Inventory Control and Organizational Performance.}

Inventory control systems are among the most important functions of materials management and it forms the nerve centre in any organization (Bidgoli, 2010). An inventory control system is a system that encompasses all aspects of managing a company's inventories; purchasing, shipping, receiving, tracking, warehousing and storage, turnover, and reordering. Inventory control helps organizations to establish the proper inventory levels through the economic order quantity and to keep track of this level through inventory control system which may be manual such as two-bin method and red line method, or computerized inventory control systems. Proper inventory controls also require an organization to undertake stocking and use the appropriate method to value stock so as not to under or overstate profits (Mols et al., 1998).

Chao (2013) noted that inventory control involved a systematic control and regulation of the purchase, storage, and usage of materials in such a way to maintain an even flow. In recent years, the construction industry has been facing several challenges especially in inventory management or material control, thus affecting the performance of most construction companies. There have been cases of material overstocking which eventually get expired or outdated, and cases of understocking due to lack of stock-taking leading to the theft of materials by workers and delays in deliveries of materials at the sites, among others (Feldman, 2010).

Inventory control can be done through the introduction of different measures to prevent the company from incurring unnecessary losses made by different departments. Measures which can be put in place include stock-taking, the accounting of stock at every end of the month so as to record the lost and available stock or making proper supervisions on sites during construction of buildings so to avoid theft of materials by workers (Singh \& Pandey, 2015).

According to Ralston et al. (2015), the main objective of inventory control is to minimize the total cost and ensure profitable operations. Because of the value attributed to inventory management, two cardinal decisions that must be made by the inventory management include answers to the questions: how much to buy at a time and when to buy (or manufacture).

According to Singh and Pandey (2015), in many cases where inventory control decisions have been effective, inventory planning models have been effective that is inventory- planning models have been developed and implemented focusing especially on the twin problems of inventory size and timing. Usually, inventory management modes are defined to achieve a balance between the costs of acquiring and holding inventory. These costs are the ones that affect organizations' profitability. These models are developed in order to help management maintain inventories of an optimal level that will help the organization to realize profits. Indeed, the major objective of inventory management models is to maintain adequate inventory levels at minimum inventory costs. They specify the economic order quantity and reorder point and if well observed, companies earn profits (Dyckhoff, Lackes \& Reese, 2013)

\section{Transportation and Organizational Performance}

Transportation plays a connective role among the several steps that result in the conversion of resources into useful goods in the name of the ultimate consumer (Trethowan \& Scullion, 1997). It is the planning of all these functions and subfunctions into a system of goods movement that minimizes cost and maximizes service to the customers that constitute the concept of business logistics. The system, once put in place must be effectively managed (Bowersox, 2006).

The channel of distribution is a system that helps in bringing products from manufacturer to final customer. Today companies use distribution channels to ensure that their product reaches customers at the right time and convenient location. These distribution channels involve intermediary organizations that help in a process to deliver products to end customers; the nation print media is not an exception to this situation (Fenez and van der Donk, 2009). Further, companies use 
intermediaries to add value to their products and to ensure that these products are closer to the target market in terms of tastes and preferences.

According to Picard (2001), the role that transportation plays in the logistics system is more complex than carrying goods for the proprietors. Its complexity can take effect only through highquality management. Through a well-handled transport system, goods could be sent to the right place at the right time in order to satisfy customers' demands. It brings efficiency and also builds a bridge between producers and consumers (Stock and Lambert, 2001). Therefore, transportation is the base of efficiency and economy in business logistics and expands other functions of the logistics system. Besides, a good transport system performing in logistics activities brings benefits not only to service quality but also to company competitiveness.

With a good responsive and economical transportation network, an organization can implement major strategic changes to reduce costs and increase customer service levels with very little disruption to the overall supply chain flow (Durgavich et al., 2008). A responsive transportation network begins with end-to-end network visibility. Visibility allows the business to centralize production operations to lower-cost areas without impacting customer service levels because any uncertainty within the network can be monitored and appropriately managed to keep inventory levels as low as possible.

\section{RESEARCH METHODOLOGY}

The study used a mixed-methods approach utilizing both qualitative and qualitative approaches. Mixed method was used because it provided a more complete and comprehensive understanding of the research problem other than either quantitative or qualitative approaches alone. We used both the case study and correlational designs.

\section{RESULTS AND DISCUSSIONS}

\section{Order Processing and Organizational Performance}

Findings on order processing and organizational performance are presented in Table 1. The following abbreviations were used; strongly agree, (SA), Agree (A), neutral (N), disagree (D) and strongly disagree $(\mathrm{SD})$.

\section{Table 1: Showing Order Processing and Organizational Performance}

\begin{tabular}{|c|c|c|c|c|c|c|c|c|c|c|c|}
\hline \multirow[b]{2}{*}{ Questionnaire Items } & \multicolumn{2}{|l|}{ SA } & \multicolumn{2}{|l|}{$\mathbf{A}$} & \multicolumn{2}{|l|}{$\mathbf{N}$} & \multicolumn{2}{|l|}{ D } & \multicolumn{2}{|c|}{ SD } & \multirow{2}{*}{$\begin{array}{l}\text { Std } \\
\text { Dev }\end{array}$} \\
\hline & $\mathbf{F}$ & $\%$ & $\mathbf{F}$ & $\%$ & $\mathbf{F}$ & $\%$ & $\mathbf{F}$ & $\%$ & $\mathbf{F}$ & $\%$ & \\
\hline $\begin{array}{l}\text { When a customer submits an order, we first revi } \\
\text { it to make sure all of the required information is th }\end{array}$ & & 36.7 & 15 & 50.0 & 3 & 10.0 & 1 & 3.3 & 0 & 0.0 & 0.912 \\
\hline $\begin{array}{l}\text { We often send timely quotations to customers } \\
\text { their orders }\end{array}$ & 10 & 33.3 & 13 & 43.3 & 2 & 6.8 & 4 & 13.3 & 1 & 3.3 & 0.791 \\
\hline Customers' orders get released in time & 14 & 46.7 & 11 & 36.7 & 4 & 13.3 & 1 & 3.3 & 0 & 0.0 & 0.911 \\
\hline $\begin{array}{l}\text { We have very few customer complaints on how } \\
\text { effectively process their orders }\end{array}$ & 12 & 40.0 & 14 & 46.7 & 0 & 0.0 & 3 & 10.0 & 1 & 3.3 & 0.908 \\
\hline We have an efficient automated ordering system & 9 & 30.0 & 18 & 60.0 & 1 & 3.3 & 2 & 6.7 & 0 & 0.0 & 0.722 \\
\hline
\end{tabular}

The findings of the study revealed that the majority $(86.7 \%)$ of the respondents agreed that the company employees first review ordered when submitted by a customer(s) submits to make sure all of the

Table 1). Majority of the respondents (76.5\%) established that when customers make their orders, the employees try as much as they can to provide required information is captured. However, the responses varied as shown by the standard deviation of 0.912 (

timely quotations. Mapunda (2014) pointed out that the accuracy, reliability, and speed with which orders are received, handled, and filled are crucial customer's service factors. 
The study findings indicated that that majority $(83.4 \%)$ of the respondents agreed that customers' orders get released in time. With the Pearson correlation coefficient of 0.579 , and a p-value of $0.000<0.05$, we note that is a positive correlation between order processing and organization performance. Hence, we reject the null hypothesis that hence orders processing significantly affect organizational performance in Rutungu Distributors Ltd. This agrees with the idea of the impacts of order processing on organizational performance as discussed by Ebert and Griffin (2012).

\section{Storage and Organizational Performance}

From Table 2, 93.3\% of the respondent affirmed that the company has been able to minimize time spent on distribution and storage whereas others 93.3\% of the respondents agreed that the company has been able to reduce stress and effort through good materials handling. Storage gives dimensions to the market for a commodity - that is - time and place utility is invested in goods through the storage process, for it involves decisions on what to store where and when. According to McKinnon (1989), the economic factors associated with storage include location, space utilization and product preservation. Storage is a marketing activity that involves holding and preserving products from the time of their production until their sale. Warehousing embraces storage plus a broad range of functions, such as assembling, breaking the bulk, dispatching as per need of middlemen, sorting/classification, providing market intelligence, preparing product for

Table 2: Showing Storage and Organizational Performance

\begin{tabular}{|c|c|c|c|c|c|c|c|c|c|c|c|}
\hline \multirow[t]{2}{*}{ Questionnaire Items } & \multicolumn{2}{|c|}{ SA } & \multicolumn{2}{|l|}{$\mathbf{A}$} & \multicolumn{2}{|l|}{$\mathbf{N}$} & \multicolumn{2}{|c|}{ D } & \multicolumn{2}{|c|}{ Sd } & \multirow{2}{*}{$\begin{array}{l}\text { Std. } \\
\text { Dev }\end{array}$} \\
\hline & $\mathbf{F}$ & $\%$ & $\mathbf{F}$ & $\%$ & $\mathbf{F}$ & $\%$ & $\mathbf{F}$ & $\%$ & $\mathbf{F}$ & $\%$ & \\
\hline $\begin{array}{l}\text { We have been able to reduce stress and effort throug } \\
\text { good materials handling }\end{array}$ & 13 & 43.3 & 15 & 50.0 & 1 & 3.3 & 1 & 3.3 & 0 & 0.0 & 1.16 \\
\hline $\begin{array}{l}\text { We have also been able to prevent accidents as a resu } \\
\text { of good materials handling }\end{array}$ & 10 & 33.3 & 17 & 56.7 & 1 & 3.3 & 2 & 6.7 & 0 & 0.0 & 1.64 \\
\hline $\begin{array}{l}\text { We have also been able to minimize time spent } \\
\text { distribution and storage }\end{array}$ & 15 & 50.0 & 13 & 43.3 & 2 & 6.7 & 0 & 0.0 & 0 & 0.0 & 1.84 \\
\hline We have also been able to eliminate redundant work. & 13 & 43.3 & 13 & 43.3 & 1 & 3.3 & 2 & 6.7 & 1 & 3.3 & 1.71 \\
\hline $\begin{array}{l}\text { The quality and condition of the products remains goo } \\
\text { as a result of proper materials managements }\end{array}$ & 12 & 40.0 & 15 & 50.0 & 0 & 0.0 & 2 & 6.7 & 1 & 3.3 & 1.12 \\
\hline
\end{tabular}

The Pearson correlation coefficient between storage and organizational performance was found to be 0.553 implying a positively significant relationship exists between storage and organization performance. The p-value of .000 that is less than $\alpha=0.05$ at the $5 \%$ level. We thus reject the null hypothesis thus storage has a significant relationship with organizational performance in Rutungu Distributors Ltd. The performance of a company is directly affected by storage practices. If products are stored correctly, all of the products that are purchased will be used to generate revenue. However, if products are not properly stored, they can be broken, damaged, or stolen. Any of those outcomes will result in increased costs. When products are purchased and paid for but then not used, more products will have to be purchased at an additional cost to generate the same amount of revenue (McKinnon, 1989).

\section{Inventory Control and Organizational Performance}

From Table 3, it can be seen that $80.7 \%$ of the respondents agreed that Rutungu Distributors Ltd invests heavily in inventory control practices. This implies that the company has tried to focus on inventory control to make it effective and efficient. Ramakrishna (2005) also argued that inventory control systems are the most important functions of materials management and it forms the nerve centre in any organization. 
East African Journal of Business and Economics, Volume 2, Issue 1, 2020

Article DOI: https://doi.org/10.37284/eajbe.2.1.163

Table 3: Inventory Control and Organizational Performance

\begin{tabular}{|c|c|c|c|c|c|c|c|c|}
\hline Questionnaire Items & $\mathbf{S A}$ & & $\mathbf{A}$ & & $\mathbf{N}$ & D & SD & Std. \\
\hline & $\overline{\mathbf{F}}$ & $\%$ & $\mathbf{F}$ & $\%$ & F & $\mathbf{F}$ & & $\mathbf{v}$ \\
\hline
\end{tabular}

Rutungu Distributors Ltd invest heavily in inventory control practices

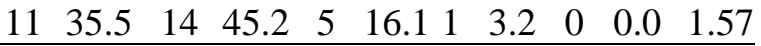

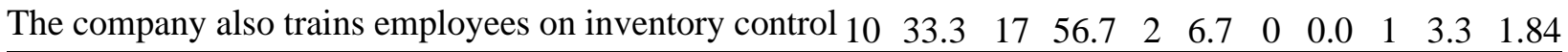

Inventory control helps us to establish the proper

inventory levels through the economic order quantity $\quad \begin{array}{rlllllllllll}9 & 30.0 & 15 & 50.0 & 4 & 13.3 & 2 & 6.7 & 0 & 0.0 & 1.76\end{array}$

We have also been able to realize profits as a result of

inventory management $\quad \begin{array}{llllllllllll}12 & 40.0 & 14 & 46.7 & 2 & 6.7 & 1 & 3.3 & 1 & 3.3 & 1.89\end{array}$

Rutungu Distributors Ltd has been able to maintain

adequate inventory levels

\begin{tabular}{lllllllllll}
6 & 20.0 & 19 & 63.3 & 1 & 3.3 & 2 & 6.7 & 2 & 6.7 & 1.75 \\
\hline
\end{tabular}

$90 \%$ of the respondents confirmed that the company also trains employees on inventory control. This is particularly important for Rutungu Distributors Ltd for consistent quality management in inventory management. One of the respondents interviewed said that;

"When we recruit new employees, we make sure that they are trained in investor management and control to enhance their skills in managing inventory."

Inventory control helps organizations to establish the proper inventory levels through the economic order quantity; and to keep track of this level through inventory control system which many be manual such as two-bin method and red line method, or computerized inventory control systems (Kotabo, 2002).

The Pearson correlation coefficient between inventory control and organizational performance was found to be 0.545 , implying that a moderate positive relationship exists between inventory control and organization performance. The null hypothesis was rejected thus there is a significant relationship between inventory control and organizational performance in Rutungu Distributors Ltd. According to Ralston et al. (2015), the main objective of inventory control is to minimize the total cost of relevant costs to ensure profitable operations.

\section{Transportation and Organizational Performance}

Majority of the respondents (76.6\%) noted that the company observe well-coordinated fleet management practices while $90 \%$ pointed out that the company also have a good vehicle maintenance policy. This implies that Rutungu Distributors Ltd has a well-coordinated transportation system in place. Transportation plays a connective role among the several steps that result in the conversion of resources into useful goods in the name of the ultimate consumer (Trethowan \& Scullion, 1997). One of the interviewed respondents said thus;

"Through a well-handled transport system, goods could be sent to the right place at the right time in order to satisfy customers' demands. It brings efficiency, and also it builds a bridge between producers and consumers."

Table 4: Transportation and Organizational Performance

\begin{tabular}{|c|c|c|c|c|c|c|c|c|c|c|c|}
\hline \multirow[t]{2}{*}{ Questionnaire Items } & \multicolumn{2}{|l|}{$\mathbf{S A}$} & \multicolumn{2}{|l|}{$\mathbf{A}$} & \multicolumn{2}{|l|}{$\mathbf{N}$} & \multicolumn{2}{|l|}{ D } & \multicolumn{2}{|c|}{ SD } & \multirow{2}{*}{$\begin{array}{l}\text { Std } \\
\text { Dev }\end{array}$} \\
\hline & $\mathbf{F}$ & $\%$ & $\mathbf{F}$ & $\%$ & $\mathbf{F}$ & $\%$ & $\mathbf{F}$ & $\%$ & $\mathbf{F}$ & $\%$ & \\
\hline $\begin{array}{l}\text { We have an effective automated transportatio } \\
\text { system }\end{array}$ & 11 & 36.7 & 15 & 50.0 & 3 & 10.0 & 1 & 3.3 & 0 & 0.0 & 0.912 \\
\hline
\end{tabular}




\begin{tabular}{|c|c|c|c|c|c|c|c|c|c|c|c|}
\hline \multirow[t]{2}{*}{ Questionnaire Items } & \multicolumn{2}{|l|}{ SA } & \multicolumn{2}{|l|}{$\mathbf{A}$} & \multicolumn{2}{|l|}{$\mathbf{N}$} & \multicolumn{2}{|c|}{$\mathbf{D}$} & \multicolumn{2}{|c|}{ SD } & \multirow{2}{*}{$\begin{array}{l}\text { Std } \\
\text { Dev }\end{array}$} \\
\hline & $\mathbf{F}$ & $\%$ & $\mathbf{F}$ & $\%$ & $\mathbf{F}$ & $\%$ & $\mathbf{F}$ & $\%$ & $\mathbf{F}$ & $\%$ & \\
\hline $\begin{array}{l}\text { We observe well-coordinated fleet managemen } \\
\text { practices }\end{array}$ & 10 & 33.3 & 13 & 43.3 & 2 & 6.8 & 4 & 13.3 & 1 & 3.3 & 0.791 \\
\hline We also have a good vehicle maintenance policy & $\mathrm{y} 10$ & 33.3 & 17 & 56.7 & 2 & 6.7 & 0 & 0.0 & 1 & 3.3 & 1.84 \\
\hline $\begin{array}{l}\text { We are able to distribute our goods in the righ } \\
\text { place at right time }\end{array}$ & 9 & 30.0 & 15 & 50.0 & 4 & 13.3 & 2 & 6.7 & 0 & 0.0 & 1.76 \\
\hline $\begin{array}{l}\text { Our transportation network has been able to } \\
\text { increase customer service levels }\end{array}$ & 12 & 40.0 & 14 & 46.7 & 2 & 6.7 & 1 & 3.3 & 1 & 3.3 & 1.89 \\
\hline
\end{tabular}

With a good responsive, economical transportation network, an organization can implement major strategic changes to reduce costs and increase customer service levels with very little disruption to the overall supply chain flow (Durgavich et al., 2008).

The Pearson correlation coefficient was found to be 0.509 indicating a rather moderate positive relationship between transportation and organization Performance. The null hypothesis was rejected hence transportation has a significant relationship with organizational performance in Rutungu Distributors Ltd. Transportation plays a connective role among the several steps that result in the conversion of resources into useful goods in the name of the ultimate consumer. It is the planning of all these functions and sub-functions into a system of goods movement in order to minimize cost maximize service to the customers that constitute the concept of business logistics. The system, once put in place, must be effectively managed (Bowersox, 2006).

\section{CONCLUSIONS AND RECOMMENDATIONS}

Based on the correlation coefficients between the study variables, there is evidence of generally moderate coefficients. These imply that although the company, Rutungu Distributors Ltd, uses a scientific approach towards its business operations, there is still a need to strive to achieve desirable levels of compliance. The fact that none of the coefficients is within the highly desirable levels of at least 0.75 means that the company can work harder to improve on its inventory control systems in order to maximize returns.
We thus recommend that the company should continue to reduce on the time it takes to get an order to a customer's premises and should also invest more in automated inventory control mechanisms to improve shelf availability and inventory turnover and to make re-ordering more efficient. We also recommend that the company applies the SIPCO (Suppliers, Input, Process, Outputs and Customers) philosophy to constantly improve their performance and thereby realize better profits.

The authors are grateful to the reviewers for their suggestions that improved the paper.

\section{REFERENCES}

Antún, J. P. (2016). Corporative trends in the Urban distribution of goods in Mexico City. Transportation research procedia, 18, 51-58.

Bidgoli, H. (2010). The handbook of technology management, supply chain management, marketing and advertising, and global management (Vol. 2). Hoboken, New Jersey: John Wiley \& Sons.

Bowersox, D. J. (2006). Logistical Management (3rd ed). Bullock, NY: Macmillan.

Britz, G. C., Emerling, D. W., Hare, L. B., Hoerl, R. W., Janis, S. J., \& Shade, J. E. (2000). Improving performance through statistical thinking. Milwaukee: ASQ Quality Press.

Chao, C. H. (2013). The framework of information processing network for supply chain innovation in big data era. In The 3rd International 
Workshop on Intelligent Data Analysis and Management (pp. 77-85). Springer, Dordrecht.

Durgavich, J., Nabirumbi. B. And Ochaka. S. (2008). Uganda: Mapping the Distribution of Commercial Goods to the Last Mile. Arlington, USAID Deliver Project, Task Order 1.

Dyckhoff, H., Lackes, R., \& Reese, J. (Eds.). (2013). Supply chain management and reverse logistics. Springer Science \& Business Media.

Ebert, R. J. \& Griffin, R. W. (2012). Business Essential ( ${ }^{\text {th }}$ Edition). Prentice-Hall.

Feldman, J. M. (1984). Transportation ChangesJust in Time. Handling and Shipping Management (September 1984), 47.

Fenez, V. D. D., \& van der Donk, M. (2009). Moving into multiple business models; outlook of newspaper publishing in the digital age. PwC Global Centre of Excellence for Publishing; Netherlands

Kapoor, S. \& Kansal, P. (2005). Basics of Distribution Management: A Logical Approach ( $3^{\text {rd }}$ Edition). New Delhi: PHI Learning Private Limited.

Kotabo K. (2002). Management of Finance Company (Sixth Edition). London, UK: International Thomson Business Press.

Kotler, P. (2001). Principles of Marketing (Second edition). Prentice-Hall.

Lai, F., Li, D., Wang, Q., \& Zhao, X. (2008). The information technology capability of thirdparty logistics providers: a resource-based view and empirical evidence from China. Journal of supply chain management, 44(3), 22-38.

LaLonde, B. J., \& Dawson, L. M. (1969). Early development of physical distribution thought. Readings in physical distribution management, 9-18.

Mapunda, D. R. (2014). Performance of physical distribution of bank Supplies and its impacts on profitability: A case of CRDB Bank plc. Doctoral dissertation. Mzumbe University.
McKinnon, A. C. (1989). Physical distribution systems. Routledge, London \& New York: Taylor \& Francis

Mols, N. P., Bukh, P. N. D., \& Nielsen, J. F. (1999). Distribution channel strategies in Danish retail banking. International Journal of Retail \& Distribution Management, 27(1), 37-47.

Picard, R. G. (2001). Strategic responses to free distribution daily newspapers. International Journal on Media Management, 3(3), 167-172.

Pirttilä, T., \& Hautaniemi, P. (1995). Activitybased costing and distribution logistics management. International journal of production economics, 41(1-3), 327-333.

Ralston, P. M., Blackhurst, J., Cantor, D. E., \& Crum, M. R. (2015). A structure-conductperformance perspective of how strategic supply chain integration affects firm performance. Journal of Supply Chain Management, 51(2), 47-64.

Ramakrishna, R. V. (2005). Materials management-profit centre. Indian Institute of Materials Management Journal, 8(6), 75-83.

Rutungu Distributors. (2017). Rutungu Distributions Ltd Financial Report 2017. Kampala, UG: Rutungu Distributions Ltd.

Singh, S. C., \& Pandey, S. K. (2015). Lean supplychain: a state-of-the-art literature review. Journal of Supply Chain Management Systems, 4(3), 33.

Stock, J. R. and Lambert, D. M. (2001). Strategic Logistics Management (4th Edition). Boston, MA: McGraw-Hill/Irwin.

Trethowan, J., \& Scullion, G. (1997). Strategic responses to change in retail banking in the UK. International Journal of Bank Marketing, 15(2), 60-68. 